\title{
CONTRIBUTION TO THE VALIDATION OF THE ANAPHASE-TELOPHASE TEST: ANEUGENIC AND CLASTOGENIC EFFECTS OF CADMIUM SULFATE, POTASSIUM DICHROMATE AND NICKEL CHLORIDE IN CHINESE HAMSTER OVARY CELLS
}

\author{
A.I. Seoane and F.N. Dulout
}

\begin{abstract}
There is increasing evidence that aneuploidy during mitosis may be a factor in the etiology of somatic malignancy. The analysis of alterations in anaphase-telophase of mitosis is a useful test for evaluating the aneuploidogenic and clastogenic ability of chemicals. Several metals have been found to be carcinogenic to humans and animals. However, the underlying mechanisms remain unclear. In the present study the aneugenic and clastogenic abilities of cadmium sulfate, potassium dichromate and nickel chloride were analyzed using the anaphase-telophase test. Chinese hamster ovary $(\mathrm{CHO})$ cells cultured for two cycles were treated with the desired compound for $8 \mathrm{~h}$ before cell harvesting. The frequency of cells with chromatin bridges, lagging chromosomes and lagging chromosomal fragments was scored. The mitotic index was determined by counting the number of mitotic cells per 1,000 cells on each coverslip and was expressed as a percentage of the number of mitotic plates. Statistical comparisons were done using the "G" method. Correlation and regression analyses were performed to evaluate variations of the mitotic index. Chromium and cadmium were clastogenic and aneugenic and increased the frequencies of the three types of aberrations scored; nickel had only aneugenic activity because it increased the frequency of lagging chromosomes. These results indicate that the anaphase-telophase test is sufficiently sensitive to detect doseresponse relationships that can distinguish clastogenic and/or aneugenic activities and that the results obtained using the anaphase-telophase test were similar to those obtained by chromosome counting.
\end{abstract}

\section{INTRODUCTION}

Although aneuploidy is a serious health problem, the experimental methodology used to investigate the condition has not been completely validated. The tests currently used to detect aneugenic compounds include chromosome counting in diploid cell lines (Danford, 1984, 1985; Dulout and Natarajan, 1987) and the fluorescence in situ hybridization (FISH) (van Diemen et al., 1995; Dulout et al., 1996; Natarajan et al., 1996). The use of diploid cell lines is necessary in order to have a low basal frequency of aneuploid cells. However, chromosome counting is time consuming even when using cells with a low chromosome number. Although accurate, FISH requires special equipment and costly reagents that are not available in most laboratories. An alternative ancillary test system is the analysis of alterations in the anaphasetelophase of cultured mitotic cells (Dulout and Olivero, 1984; Seoane and Dulout, 1994). This test is very simple and can be performed in any cytogenetic laboratory with cell culture facilities. The analysis of alterations in anaphase-telophase is restricted to the detection of lagging fragments, chromatin bridges, and lagging chromosomes. Lagging fragments arising from chromosome breaks and chromatin bridges are considered indicators of exchangetype aberrations. Lagging chromosomes are presumably produced by alterations at the level of the kinetochore

Centro de Investigaciones en Genética Básica y Aplicada (CIGEBA), Facultad de Ciencias Veterinarias, Universidad Nacional de La Plata, 60 y 118, CC 296, 1900 La Plata, Argentina. Send correspondence to A.I.S.
(Dulout and Olivero, 1984; Seoane and Dulout, 1994). Validation of the anaphase-telophase test has been done using heavy metal salts such as cadmium sulfate, potassium dichromate and nickel chloride. These compounds were selected based on their mutagenic and carcinogenic capacity and on previous results with cadmium chloride (Seoane and Dulout, 1994).

Compared to laboratory animals little is known of the carcinogenicity of cadmium compounds in humans (IARC, 1990). The ability of cadmium to induce genotoxicity in vivo and in vitro is well known (Lakkad et al., 1986; Oberdorster, 1989; Tang et al., 1990; Howard, 1991). Saplakoglu and Iscan (1998) recently reported sister chromatid exchanges (SCE) induced by cadmium chloride $\left(10^{-7}-10^{-3} \mathrm{M}\right)$, whereas Coogan et al. (1992) and Dally and Hartwig (1997) found that cadmium II induced single strand breaks at concentrations of $500 \mu \mathrm{M}$ and 10 $\mu \mathrm{M}$, respectively. The induction of aneuploidy during meiosis in mice has been reported (Selypes et al., 1992). Cadmium chloride at concentrations of $0.5-4 \mu \mathrm{M}$ has an aneugenic effect on Chinese hamster ovary $(\mathrm{CHO})$ cells (Seoane and Dulout, 1994), and inhibits microtubule assembly at concentrations of 10-1000 $\mu \mathrm{M}$ (Wallin et al., 1985; Andersen and Ronne, 1990).

The genotoxicity of $\mathrm{Cr}$ (VI) has been extensively studied with some authors reporting an increase in the frequency of single strand breaks (Gao et al., 1992; Manning et al., 1994) and higher frequency of micronucleus (Howard et al., 1992; Godet et al., 1996). Costa (1991) demostrated the formation of DNA-protein complexes by chromate. Little is known about other cadmium-induced genotoxic endpoints such as aneuploidy. Sora et al. (1986) 
reported the aneugenic effects of potassium dichromate (0.07-0.85 mM) in Saccharomyces cerevisiae. Some reports have shown that chromate can induce cellular transformation up to $200 \mu \mathrm{M}$ (Lanfranchi et al., 1988; Biedermann and Landolph, 1990). Li et al. (1992) found that microtubules bind $3.13 \mu \mathrm{M}$ potassium dichromate for $16 \mathrm{~h}$ and that microtubule depolymerization and disruption occurred in 3T3 cells at concentrations of $25 \mu \mathrm{M}$.

There is substantial evidence for nickel carcinogenicity in humans (IARC, 1990). Nickel can induce DNAbreakage (Stinson et al., 1992; Saplakoglu et al., 1997) and DNA-protein crosslinking (Patierno and Costa, 1985; Zhuang et al., 1994; Lei et al., 1995). Hartwig and Beyersmann (1989) showed that nickel chloride was cytotoxic and mutagenic in V79 cells treated with concentrations of 0.5-2 mM for $5 \mathrm{~h}$. Littlefield et al. (1994) reported that this salt $(100 \mu \mathrm{M} / \mathrm{l}$ for $16 \mathrm{~h})$ induced DNA strand breaks in a human B-lymphoblastoid cell line and in rat primary splenocytes. Au et al. (1994) found no increase in SCE and chromosomal aberrations in lymphocytes exposed to $0.1-100 \mu \mathrm{M}$ for $1 \mathrm{~h}$. Patierno et al. (1993) reported that nickel sulfate was cytotoxic to rat epithelial cells at doses of $50-200 \mu \mathrm{g} / \mathrm{ml}$ and induced transformation in these cells.

The objective of this study is to analyze the aneugenic and clastogenic abilities of cadmium sulfate, potassium dichromate and nickel chloride using the anaphase-telophase test, and to validate, if possible, the usefulness of such analysis to distinguish between these two mentioned kinds of genetic damage.

\section{MATERIAL AND METHODS}

CHO cells obtained from the American Type Culture Collection were cultured in Ham's F10 medium (Gibco) supplemented with $10 \%$ fetal bovine serum and antibiotics (50 IU penicillin and $50 \mu \mathrm{g}$ streptomycin/ml).

Metal salts were obtained from Sigma Chemical
Company (St. Louis, MO, USA.) and were dissolved in bidistilled water. One hundred microliters of stock solution was added to each culture containing $10 \mathrm{ml}$ of culture medium to give final concentrations of $0.033,0.067$ and $0.134 \mu \mathrm{M}$ cadmium sulfate; $1,2,3$ and $4 \mu \mathrm{M}$ potassium dichromate and 0.003, 0.006, 0.009 and $0.012 \mu \mathrm{M}$ nickel chloride. These concentrations were selected based on pilot experiments, and represented the highest levels that could be studied. Untreated cultures were used as controls.

The cells were cultured as monolayers on 24 x 36$\mathrm{mm}$ glass coverslips attached to a small drop of siliconized grease (Merck) to the bottom of $90-\mathrm{mm}$ diameter Petri dishes. Three coverslips were placed in each Petri dish. Each coverslip was seeded with $1.5 \mathrm{ml}$ of culture medium containing about 50,000 cells. After one hour, $8.5 \mathrm{ml}$ of culture medium was added to each Petri dish followed by incubation at $37^{\circ} \mathrm{C}$ in a humidified atmosphere of $5 \%$ $\mathrm{CO}_{2}$. Treatments were performed during the logarithmic growth phase. The cells were treated simultaneously $8 \mathrm{~h}$ before cell harvesting. To avoid detachment of the cells from coverslips, the cells were harvested by adding an equal volume of fixative (methanol:acetic acid 3:1 v/v) to the culture medium. The fixative was changed twice at 10-min intervals. The coverslips were stained with carbol fuchsin and attached with DPX mounting medium to coded slides. Each treatment was performed in quadruplicate.

The coded slides were analyzed by one investigator. A total of 1,000 cells per treatment were scored. To avoid the erroneous scoring of chromatin bridges and lagging chromosomes or fragments, the cells were analyzed in late anaphase-early telophase. In early or middle anaphase, chromosome arms cannot be distinguished from chromatin bridges and lagging chromosomes or fragments may be masked by chromosome arms. The frequency of cells with chromatin bridges, lagging chromosomes and lagging chromosomal fragments was scored (Figures 1 A-D). The
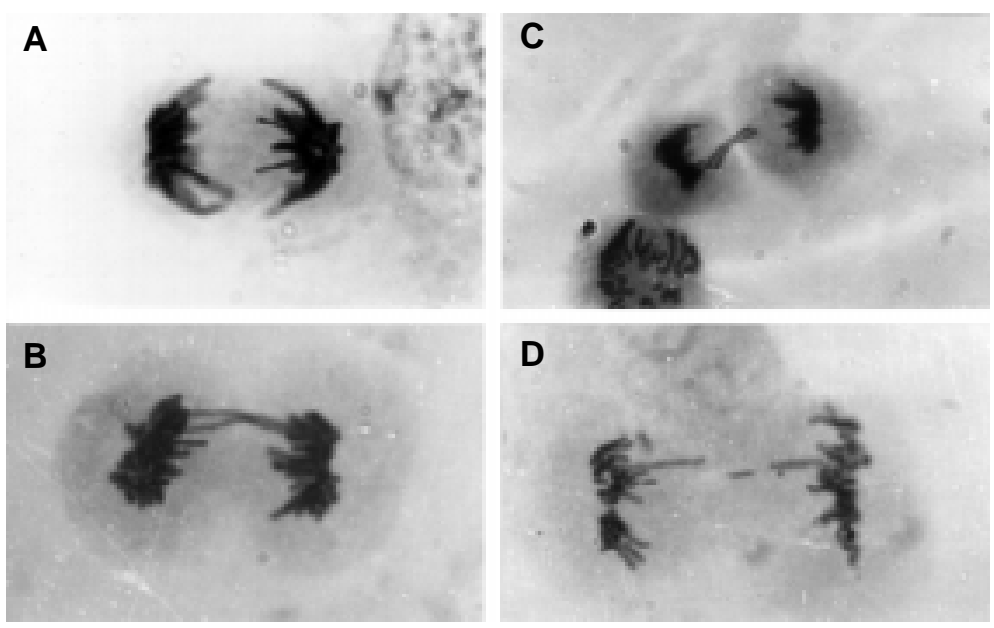

D

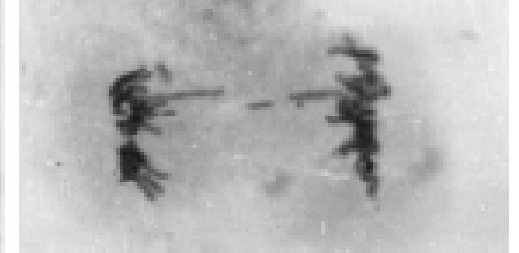

Figure 1 - A, Normal anaphase. B, Anaphase with a chromatin bridge. C, Anaphase with a lagging chromosome. D, Anaphase with a lagging fragment. 
mitotic index was determined by counting the number of mitotic cells per 1,000 cells on each coverslip and was expressed as the percentage of mitotic plates.

Statistical comparisons were done using the "G" method of Sokal and Rohlf (1979), which is a frequency comparison test for non-parametric variables. Correlation and regression analyses were used to evaluate the variations in the mitotic index.

\section{RESULTS}

Cadmium sulfate increased the frequencies of chromatid bridges, lagging fragments and lagging chromosomes (Table I), although this was significantly different from the untreated controls only at the highest dose $(\mathrm{G}=$ 9.71, $\mathrm{P}<0.01$ for lagging chromosomes; $\mathrm{G}=6.88, \mathrm{P}<$ 0.01 for lagging fragments; $\mathrm{G}=8.41, \mathrm{P}<0.01$ for chromatin bridges). Variations of mitotic index were inversely correlated with dose $(\mathrm{r}=0.868, \mathrm{P}=0.068)$.

Potassium dichromate increased the frequencies of lagging chromosomes at the four doses $(\mathrm{G}=10.12$, $\mathrm{P}$ $<0.01 ; \mathrm{G}=17.02, \mathrm{P}<0.001 ; \mathrm{G}=14.32, \mathrm{P}<0.001$, and $\mathrm{G}=22.74, \mathrm{P}<0.001$, respectively) (Table II). The frequency of lagging fragments increased significantly at the three highest doses $(\mathrm{G}=11.03, \mathrm{P}<0.001 ; \mathrm{G}=7.39$, $\mathrm{P}<0.01$, and $\mathrm{G}=9.80, \mathrm{P}<0.01$, respectively) whereas the frequency of chromatin bridges increased significantly $(\mathrm{G}=8.76, \mathrm{P}<0.01 ; \mathrm{G}=27.90, \mathrm{P}<0.001$, respectively $)$ only at the two highest concentrations. Variations of mitotic index were inversely correlated with dose $(r=0.899$, $\mathrm{P}=0.013$ ).

Nickel chloride increased only the frequency of lagging chromosomes (Table III). However, significant differences from the controls were found only between cells treated with the second $(\mathrm{G}=9.73, \mathrm{P}<0.01)$ and fourth $(\mathrm{G}$ $=7.78, \mathrm{P}<0.01)$ doses. No effect on the mitotic index was observed, except at the highest dose; the regression analysis was not significant $(\mathrm{r}=0.50, \mathrm{P}=0.181)$.

\section{DISCUSSION}

The induction of lagging chromosomes in anaphase-telophase is an indication of aneugenic ability (Seoane and Dulout, 1994) whereas the induction of lagging fragments and chromatin bridges signals clastogenic activity. Consequently, the anaphase-telophase test can detect both aneugenic and/or clastogenic compounds.

The carcinogenicity and genotoxicity of cadmium, chromium and nickel strongly depends on their chemical ligands which modulate their bioavailability and reactivity with biochemical targets. With the exception of hexavalent chromium, carcinogenic metal compounds are only weakly genotoxic (Beyersmann, 1994). Nevertheless our results showed that the three cations were genotoxic (chromium and cadmium were clastogenic and aneugenic, and nickel was aneugenic).
Table I - Anaphase-telophase alterations induced by cadmium sulfate (CS) in CHO cells.

\begin{tabular}{|lcccc|}
\hline \multirow{2}{*}{ Treatment } & \multicolumn{3}{c}{$\begin{array}{c}\text { Anaphase-telophase alterations } \\
\text { per 100 cells }\end{array}$} & $\begin{array}{c}\text { Mitotic } \\
\text { index } \\
\end{array}$ \\
\cline { 2 - 4 } & CB & LC & LF & \\
\hline Control & $0.60 \pm 0.07 *$ & $1.00 \pm 0.09$ & $0.80 \pm 0.08$ & 2.32 \\
CS $0.033 \mu \mathrm{M}$ & $1.84 \pm 0.13$ & $1.07 \pm 0.10$ & $1.15 \pm 0.03$ & 2.40 \\
CS $0.067 \mu \mathrm{M}$ & $2.00 \pm 0.14$ & $1.60 \pm 0.12$ & $0.60 \pm 0.07$ & 2.00 \\
CS $0.134 \mu \mathrm{M}$ & $4.28 \pm 0.20$ & $5.71 \pm 0.23$ & $4.28 \pm 0.20$ & 0.45 \\
\hline
\end{tabular}

* Mean \pm standard error of the mean. CB: Chromatin bridges. LC: Lagging chromosomes. LF: Lagging fragments.

Table II - Anaphase-telophase alterations induced by potassium dichromate (PD) in $\mathrm{CHO}$ cells.

\begin{tabular}{|lcccc|}
\hline \multirow{2}{*}{ Treatment } & \multicolumn{3}{c}{$\begin{array}{c}\text { Anaphase-telophase alterations } \\
\text { per 100 cells }\end{array}$} & $\begin{array}{c}\text { Mitotic } \\
\text { Index } \\
\end{array}$ \\
\cline { 2 - 4 } & \multicolumn{3}{c}{ CB } \\
& LC & LF & \\
\hline Control & $0.99 \pm 0.09^{*}$ & $1.10 \pm 0.10$ & $0.10 \pm 0.03$ & 2.18 \\
PD 1 $\mu \mathrm{M}$ & $1.40 \pm 0.11$ & $3.10 \pm 0.17$ & $0.80 \pm 0.08$ & 2.08 \\
PD 2 $\mu \mathrm{M}$ & $1.60 \pm 0.12$ & $3.90 \pm 0.19$ & $1.20 \pm 0.10$ & 1.27 \\
PD 3 $\mu \mathrm{M}$ & $2.60 \pm 0.15$ & $3.60 \pm 0.18$ & $0.90 \pm 0.09$ & 1.18 \\
PD 4 $\mu \mathrm{M}$ & $4.60 \pm 0.20$ & $4.50 \pm 0.20$ & $1.10 \pm 0.10$ & 0.96 \\
\hline
\end{tabular}

*Mean \pm standard error of the mean. For abbreviations see legend to Table I.

Table III - Anaphase-telophase alterations induced by nickel chloride (NC) in CHO cells.

\begin{tabular}{|c|c|c|c|c|}
\hline \multirow[t]{2}{*}{ Treatment } & \multicolumn{3}{|c|}{$\begin{array}{l}\text { Anaphase-telophase alterations } \\
\text { per } 100 \text { cells }\end{array}$} & \multirow{2}{*}{$\begin{array}{c}\text { Mitotic } \\
\text { index } \\
(\%)\end{array}$} \\
\hline & $\mathrm{CB}$ & $\mathrm{LC}$ & LF & \\
\hline Control & $0.40 \pm 0.06^{*}$ & $0.40 \pm 0.06$ & $0.00 \pm 0.00$ & 2.35 \\
\hline $\mathrm{NC} 0.013 \mathrm{mM}$ & $0.30 \pm 0.05$ & $1.00 \pm 0.09$ & $0.10 \pm 0.03$ & 2.35 \\
\hline NC $0.027 \mathrm{mM}$ & $0.20 \pm 0.04$ & $1.80 \pm 0.13$ & $0.20 \pm 0.40$ & 2.35 \\
\hline $\mathrm{NC} 0.040 \mathrm{mM}$ & $0.40 \pm 0.06$ & $1.30 \pm 0.11$ & $0.30 \pm 0.05$ & 2.35 \\
\hline $\mathrm{NC} 0.054 \mathrm{mM}$ & $0.50 \pm 0.07$ & $1.60 \pm 0.12$ & $0.30 \pm 0.05$ & 1.55 \\
\hline
\end{tabular}

* Mean \pm standard error of the mean. For abbreviations see legend to Table I.

Cadmium salt produced significant damage only at the highest concentration $\left(0.134 \mu \mathrm{M}=0.1 \times 10^{-2} \mu \mathrm{g} \mathrm{Cd} /\right.$ $\mathrm{ml}$ ). This salt has higher toxicity than cadmium chloride, which is active only at doses up to $4 \mu \mathrm{M}$ (Seoane and Dulout, 1994).

Potassium dichromate produced lagging chromosomes in a dose-dependent manner. The concentration range used (1-4 $\mu \mathrm{M})$ was lower than that which induced aneuploidy in Saccharomyces cerevisiae (Sora et al., 1986) and similar to or lower than doses able to induce cellular transformation in Syrian hamster cells and BHK fibroblasts (Lanfranchi et al., 1988). 
Nickel chloride increased the frequency of lagging chromosomes. The frequencies of lagging fragments and chromatin bridges were not significantly different from the controls. Nevertheless, others have reported increased frequencies with higher concentrations $(0.5-2 \mathrm{mM}$ for $5 \mathrm{~h}$ ) (Hartwig and Beyersmann, 1989). Littlefield et al. (1994) found that $\mathrm{Ni}$ (II) was less genotoxic than $\mathrm{Cd}$ (II) at the same dose. Our results showed that Ni (II) had little or no clastogenic activity under the experimental conditions employed. According to Au et al. (1994), nickel compounds are weakly mutagenic and may therefore be carcinogenic because of non-conventional genotoxic mechanisms including aneuploidy. On the other hand, the concentrations employed in these experiments may have been too low to induce DNA breakage.

The main cause of mitotic aneuploidy is nondisjunction, although chromosomal delay, chromatid missegregation, and monopolar division (Ford and Correl, 1991) must also be considered. Like another aneuploidy inducers, cadmium chloride modifies the microtubular organization and reduces the fidelity of the splindle apparatus in Hordeum vulgare (Voutsinas et al., 1997). Chromium (VI) readily enters cell through non-specific anion channels and reactive intermediates formed during intracellular $\mathrm{Cr}$ (VI) reduction may be responsible for some of this compound's genotoxicity (Biedermann and Landolph, 1990; De Flora et al., 1990; Katz and Salem, 1993). There is more than one explanation for chromate-induced aneuploidy. Li et al. (1992) suggested that this effect could be related to cytoskeletal damage which may result from the direct inhibition of cytoskeletal protein synthesis. Bridgewater et al. (1994) suggested that the interference with DNA replication by chromium-mediated DNA-DNA cross-linking at the level of the centromere may give rise to lagging chromosomes. Nevertheless, the mechanisms by which these metal salts induced aneuploidy remain uncertain.

All of the compounds tested are cytotoxic, although in the case of $\mathrm{Ni}$ (II) this effect was weak since it was seen only at the highest concentration.

These results may indicate that the anaphase-telophase test for detecting aneugenic/clastogenic compounds is sensitive enough to detect dose-response relationships, that it can identify clastogenic and/or aneugenic compounds, and that the results obtained are similar to those obtained by chromosome counting (Seoane and Dulout, 1994). Nevertheless, further validation of this test is still required.

\section{RESUMO}

As evidências de que a aneuploidia durante a mitose pode ser um fator na etiologia de malignidades somáticas estão cada vez mais fortes. A análise de alterações em anáfase-telófase da mitose é um teste útil para a avaliação da capacidade aneuploidogênica e clastogênica de substâncias químicas. Vários metais têm sido identificados como carcinogênicos para o homem e para animais. Contudo, os mecanismos de ação permanecem obscuros. No presente estudo, a capacidade aneugênica e clastogênica do sulfato de cádmio, do dicromato de potássio e do cloreto de níquel foi analisada usando o teste anáfase-telófase. Células do ovário do hamster chinês cultivadas por dois ciclos foram tratadas com o composto desejado por 8 horas antes da colheita das células. Foram quantificadas as frequiências de células com pontes de cromatina, lagging cromossomos e lagging fragmentos cromossômicos. O índice mitótico foi determinado pela contagem do número de células em mitose por 1000 células em cada lamínula e foi expresso como uma porcentagem do número de placas mitóticas. A análise estatística foi feita usando o método " $\mathrm{G}$ ". Análises de correlação e de regressão foram realizadas para avaliar as variações do índice mitótico. O crômio e o cádmio foram clastogênicos e aneugênicos e aumentaram as frequiências dos três tipos de aberrações avaliadas; o níquel teve apenas atividade aneugênica porque ele aumentou a freqüência de lagging cromossomos. Estes resultados indicam que o teste anáfasetelófase é sensível o suficiente para detectar as relações dependentes da dose que podem distinguir as atividades clastogênicas e/ou aneugênicas e que os resultados obtidos usando o teste anáfase-telófase foram semelhantes aos obtidos pela contagem cromossômica.

\section{REFERENCES}

Andersen, O. and Ronne, M. (1990). Spindle-inhibiting effects of metal compouds studied by chromosome length measurement. In: Scand. Cell Toxicol. Congr. Altern. Lab. Anim. 17: 163-167.

Au, W., Heo, M. and Chiewchanwit, T. (1994). Toxicological interactions between nickel and radiation on chromosome damage and repair. Environ. Health Perspect. 102: 73-77.

Beyersman, D. (1994). Interactions in metal carcinogenicity. Toxicol. Lett. 72: $333-338$

Biedermann, K. and Landolph, J. (1990). Role of valence state and solubility of chromium compounds on induction of cytotoxicity, mutagenesis and anchorage independence in diploid human fibroblasts. Cancer Res. 50: 7835-7842.

Bridgewater, L., Manning, F., Woo, E. and Patierno, S. (1994). DNA polymerase arrest by adducted trivalent chromium. Mol. Carcinog. 9: $122-133$.

Coogan, T., Bare, R. and Waalkes, M. (1992). Cadmium-induced DNA strand damage in cultured liver cells: reduction in cadmium genotoxicity following zinc pretreatment. Toxicol. Appl. Pharmacol. 113: 227-233.

Costa, M. (1991). DNA-protein complexes induced by chromate and other carcinogens. Environ. Health Perspect. 92: 45-52.

Dally, H. and Hartwig, A. (1997). Induction and repair inhibition of oxidative DNA damage by nickel(II) and cadmium(II) in mammalian cells. Carcinogenesis 18: 1021-1026.

Danford, N. (1984). Measurements of levels of aneuploidy in mammalian cells using a modified hypotonic treatment. Mutat. Res. 139: 127132 .

Danford, N. (1985). Tests for chromosome aberrations and aneuploidy in Chinese hamster fibroblast cell line CH1-L. In: Progress in Mutation Research (Ashby, J., De Serres, F.J., Draoer, M., Ishidate Jr., M. Margolin, B.H., Matter, B.E. and Shelby, M.D., eds.). Vol. 5. Elsevier, Amsterdam, pp. 397-411.

De Flora, S., Bagnasco, M., Serra, D. and Zanacchi, P. (1990). Genotoxicity of chromium compounds. A review. Mutat. Res. 238: 90-172.

Dulout, F.N. and Natarajan, A.T. (1987). A simple and reliable in vitro test system for the analysis of induced aneuploidy as well as other cytogenetic end-points using Chinese hamster cells. Mutagenesis 2: 121-126.

Dulout, F.N. and Olivero, O. (1984). Anaphase-telophase anaysis of chro- 
mosomal damage induced by chemicals. Environ. Mutagen. 6: 299310

Dulout, F.N., Grillo, C.A., Seoane, A.I., Maderna, C.R., Nilsson, R., Vahter, M., Darroudi, F. and Natarajan, A.T. (1996). Chromosomal aberrations in peripheral lymphocytes from Andean women and children from northwestern Argentina exposed to arsenic in drinking water. Mutat. Res. 370: 151-158.

Ford, J. and Correl, A. (1991). Chromosome errors at mitotic anaphase. Genome 35: 702-705.

Gao, M., Binks, S., Chipman, J., Levy, L., Braithwaite, R. and Brown, S. (1992). Induction of DNA strand breaks in peripheral lymphocytes by soluble chromium compounds. Hum. Exp. Toxicol. 11: 7782.

Godet, F., Babut, M., Burnel, D., Veber, A. and Vasscur, P. (1996). The genotoxicity of iron and chromium in electroplating effluents. Mutat. Res. 370: 19-28.

Hartwig, A. and Beyersmann, S. (1989). Enhancement of UV-induced mutagenesis and sister-chromatid exchanges by nickel ions in V79 cells: evidence for inhibition of DNA repair. Mutat. Res. 217: 65-73.

Howard, W. (1991). Induction of chromosome changes by metal compounds in cultured CHO cells. Toxicol. Lett. 56: 179-186.

Howard, W., Hoffman, S. and Kochhar, T. (1992). Enhanced induction of micronuclei by hexavalent chromium in cultured $\mathrm{CHO}$ cells. Bull. Environ. Contam. Toxicol. 49: 535-540.

IARC Sci. Publ. (1990). IARC Monographs on the Evaluation of the Carcinogenic Risk of Chemicals to Humans. Vol. 49. Chromium, Nickel and Welding. International Agency for Cancer Research, Lyon.

Katz, S. and Salem, H. (1993). The toxicology of chromium with respect to its chemical speciation: a review. J. Appl. Toxicol. 13: 217-224.

Lakkad, B., Nigam, S., Karnik, A., Thakore, K. and Chaterjee, B. (1986). Effect of cadmium chloride on cell division and chromosomes in Chinese hamster ovary cells. Bull. Environ. Contam. Toxicol. 36 : 342-349.

Lanfranchi, G., Paglialunga, S. and Levis, L. (1988). Mammalian cell transformation induced by chromium (VI) compound in the presence of nitrilotriacetic acid. J. Toxicol. Environ. Health 24: 251-260.

Lei, Y., Zhang, Q. and Zhuang, Z. (1995). An in vivo study on DNAprotein crosslinks induced by nickel chloride. Chung Ниа Yи Fang $I$ Hsueh Tsa Chih 29: 202-204.

Li, W., Zhao, Y. and Chou, I. (1992). Cytoskeletal injury induced by hexavalent chromate. Toxicol. In Vitro 6: 433-444.

Littlefield, N., Hass, B., James, S. and Poirier, S. (1994). Protective effects of magnesium on DNA strand breaks induced by nickel or cadmium. Cell Biol. Toxicol. 10: 127-135.

Manning, F., Blankenship, L., Wise, J., Bridgewater, L. and Patierno, S. (1994). Induction of internucleosomal DNA fragmentation by carcinogenic chromate: relationship to DNA damage, genotoxicity, and inhibition of macromolecular synthesis. Environ. Health Perspect. 102: 159-167.

Natarajan, A.T., Boei, J.J.W.A., Darroudi, F., Van Diemen, P.C.M., Dulout, F.N., Hande, M.P. and Ramalho, A.T. (1996). Current cy- togenetic methods for detecting exposures and effects of mutagens and carcinogens. Environ. Health Perspect. 104 (Suppl. 3): 445-448

Oberdorster, G. (1989). Pulmonary toxicity and carcinogenicity of cadmium. J. Am. Coll. Toxicol. 8: 1251-1263.

Patierno, S. and Costa, M. (1985). DNA-protein crosslinks induced by nickel compounds in intact cultured mammalian cells. Chem.-Biol. Interact. 55: 75-91.

Patierno, S., Dirscherl, L. and Xu, J. (1993). Transformation of rat tracheal epithelial cells to inmortal growth variants by particulate and soluble nickel compounds. Mutat. Res. 300: 179-193.

Selypes, A., Serényi, P., Boldog, F., Bokros, F. and Takács, S. (1992). Acute and long term genotoxic effects of $\mathrm{CdCl}_{2}$ on testes of mice. $J$. Toxicol. Environ. Health 36: 401-409.

Seoane, A. and Dulout, F. (1994). Use of anaphase-telophase test to detect aneugenic compounds: effects of propionaldehyde and cadmium chloride. Bull. Environ. Contam. Toxicol. 53: 924-929.

Sokal, R. and Rohlf, F. (1979). Biometría. Principios y Métodos Estadísticos en la Investigación Biológica. H. Blume eds., Madrid.

Sora, S., Agosti Carbone, M., Pacciarini, M. and Magni, G. (1986). Disomic and diploid meiotic products induced in Saccharomyces cerevisiae by the salts of 27 elements. Mutagenesis 1: 21-28.

Saplakoglu, U. and Iscan, M. (1998). Sister chromatid exchanges in human lymphocytes treated in vitro with cadmium in $\mathrm{G}_{(0)}$ and $\mathrm{S}$ phase of their cell cycles. Mutat. Res. 412: 109-114.

Saplakoglu, U., Iscan, M. and Iscan, M. (1997). DNA-single strand breakage in rat lung, liver and kidney after single and combined treatment of nickel and cadmium. Mutat. Res. 394: 133-140.

Stinson, T., Jaw, S., Jeffery, E. and Plewa, M. (1992). The relationship between nickel chloride-induced peroxidation and DNA strand breakage in rat liver. Toxicol. Appl. Pharmacol. 117: 98-103.

Tang, X., Chen, X., Zhang, J. and Qin, W. (1990). Cytogenetic investigation in lymphocytes of people living in cadmium-polluted areas. Mutat. Res. 241: 243-249.

van Diemen, P.C.M., Maasdam, D., Vermeulen, S., Darroudi, F. and Natarajan, A.T. (1995). Influence of smoking habits on the frequencies of structural and numerical chromosome aberrations in human peripheral blood lymphocytes using the fluorescence in situ hybridization (FISH) technique. Mutagenesis 10: 487-495.

Voutsinas, G., Zarani, F. and Kappas, A. (1997). The effect of environmental aneuploidy-inducing agents on the microtubule architecture of mitotic meristematic root cells in Hordeum vulgare. Cell. Biol. Int. 21: 411-418.

Wallin, M., Fridén, B. and Billger, M. (1985). Studies of the interaction of chemicals with microtubule assembly in vitro can be used as an assay for detection of cytotoxic chemicals and possible inducers of aneuploidy. Mutat. Res. 201: 303-311.

Zhuang, Z., Huang, X. and Costa, M. (1994). Protein oxidation and amino acid-DNA crosslinking by nickel compounds in intact cultured cells. Toxicol. Appl. Pharmacol. 126: 319-325.

(Received September 21, 1998) 
